\title{
Dermatosis as the Initial Manifestation of Malignant Breast Tumors: Retrospective Analysis of 4 Cases
}

\author{
Ying-Jie Song ${ }^{\mathrm{a}}$ Yun-Fei Wu $\mathrm{Tao} \mathrm{Fan}^{\mathrm{b}}$ \\ ${ }^{\text {a }}$ Department of Breast Surgery, \\ ${ }^{\mathrm{b}}$ Department of Oncology Surgery, the First Affiliated Hospital of China Medical University, Liaoning, China
}

\section{Key Words}

Dermatomyositis - Acquired ichthyosis .

Malignant breast tumor

\section{Summary}

Background: The aim of this study was to explore the clinical characteristics, diagnosis, treatment, and prognostic factors of dermatosis associated with malignant breast tumors. Case Reports: The clinical data of 4 breast cancer patients, 3 with dermatomyositis and 1 with acquired ichthyosis, were analyzed retrospectively. The 4 patients were $>50$ years of age, and the malignant breast tumors appeared within 5 years of the diagnosis of dermatosis. Two of the 3 breast cancer patients with dermatomyositis received a modified radical mastectomy, and because they could not afford systemic chemotherapy after surgery, only received endocrine therapy. The third patient received a simple mastectomy and axillary lymph node dissection but died of respiratory failure 2 months after the operation. The patient with acquired ichthyosis and malignant breast tumor received modified radical mastectomy, chemotherapy, radiotherapy, and endocrine therapy; no complications were observed in the postoperative period. During the 9-15 months of follow-up after the surgery, the 3 patients remained in good condition with improvement of the dermatosis symptoms and no cancer relapse. Conclusions: Malignant breast tumor screening is indicated in women with dermatomyositis or acquired ichthyosis, especially in those aged $>50$ years.

\author{
Schlüsselwörter \\ Dermatomyositis - Erworbene Ichthyose . \\ Mammakarzinom
}

\section{Zusammenfassung}

Hintergrund: Ziel dieser Studie war es, klinische Eigenschaften, Diagnose, Behandlung und Prognosefaktoren von Dermatosen assoziiert mit Mammakarzinomen zu untersuchen. Fallberichte: Die klinischen Daten von 4 Brustkrebspatientinnen wurden retrospektiv analysiert; 3 der Patientinnen hatten eine Dermatomyositis und 1 Patientin hatte eine erworbene Ichthyose. Die 4 Patientinnen waren >50 Jahre alt. Die Mammakarzinome traten innerhalb von 5 Jahren nach Feststellung der Dermatosen auf. Zwei der 3 Brustkrebspatientinnen mit Dermatomyositis erhielten eine modifizierte, radikale Mastektomie. Da eine postoperative systemische Chemotherapie die finanziellen Möglichkeiten dieser Patientinnen überstieg, wurden sie im Weiteren nur endokrin behandelt. Bei der dritten Patientin wurde eine einfache Mastektomie und axilläre Lymphonodektomie durchgeführt. Sie verstarb jedoch an Lungenversagen 2 Monate nach der Operation. Die Brustkrebspatientin mit erworbener Ichthyose erhielt eine modifizierte, radikale Mastektomie, Chemotherapie, Radiotherapie und endokrine Therapie ohne postoperative Komplikationen. Während des 9-15 monatigen Follow-ups nach dem chirurgischen Eingriff verblieben die 3 Patientinnen in guter Verfassung. Die Dermatose-Symptome verbesserten sich, und es traten keine Mammakarzinomrezidive auf. Schlussfolgerungen: Bei Patientinnen mit Dermatomyositis oder erworbener Ichthyose ist ein Mammakarzinom-Screening indiziert, insbesondere bei Frauen im Alter von >50 Jahren.

\section{KARGER}

Fax +497614520714

Information@Karger.de

www.karger.com (c) 2010 S. Karger GmbH, Freiburg

Accessible online at:

www.karger.com/brc
Yun-Fei Wu

Department of Breast Surgery

The First Affiliated Hospital of China Medical University

Shenyang, Liaoning, 110001, China

Tel. +86 15524447559

songyingiie1980@yahoo.cn 


\section{Introduction}

Dermatomyositis is an idiopathic inflammatory myopathy with characteristic cutaneous findings. On average, $25 \%$ of adult patients have an associated occult malignancy, most commonly ovarian, breast, lung, and gastrointestinal carcinomas. The dermatomyositis and cancer association is well established $[1,2]$. Acquired ichthyosis is occasionally associated with malignant disease, especially breast cancer [3-6]. Here, we report on 4 breast cancer patients with dermatosis, 3 with dermatomyositis and 1 with acquired ichthyosis. We retrospectively reviewed the data of breast cancer patients with dermatosis to better understand the clinical course and the relationship between the conditions.

\section{Patients and Methods}

From June 2008 to December 2008, a total of 173 consecutive patients with histopathologically proven malignant breast tumors were treated at the Department of Breast Surgery, First Affiliated Hospital of China Medical University, Shenyang, China. Among them were 4 patients with concurrent dermatosis, 3 with dermatomyositis and 1 with acquired ichthyosis. Acquired ichthyosis was diagnosed as defined by Patel et al. [7]. Dermatomyositis was diagnosed as defined by Bohan et al. [8]. The dermatosis preceded the breast carcinoma in all 4 patients. The malignant breast tumor was staged according to the American Joint Committee on Cancer (AJCC) system for breast carcinoma. Clinical features, laboratory data, diagnosis, treatment, and prognostic factors were assessed. The outcome of all patients was examined through a follow-up study via telephone contact.

\section{Results}

The mean age at diagnosis of the 4 breast cancer patients with dermatosis was 55.7 years. The 3 patients with dermatomyositis had muscle weakness and scaly erythematous patches on the face, trunk, and extremities as well as various other cutaneous manifestations. Two of the 3 patients received a modified radical mastectomy, and had 14/21 and 0/17 metastatic lymph nodes, respectively. The third patient received a simple mastectomy and axillary lymph node dissection, and had 13/22 metastatic lymph nodes. The patient with acquired ichthyosis had scaly erythematous patches on the trunk and extremities (fig. 1), and 10/25 metastatic lymph nodes; a modified radical mastectomy was carried out. Of the 4 patients, 3 had IIIC (T3N3M0/T2N3M0) breast tumors, and 1 had a IIA (T2N0M0) breast tumor (table 1). The malignant breast tumors occurred in all 4 women within a mean period of 39 (range 24-60) months after the diagnosis of dermatosis.

\section{Discussion}

Dermatomyositis is a disease of unknown etiology characterized by proximal muscle weakness and specific cutaneous signs. Its clinical significance lies in the fact that it may be a

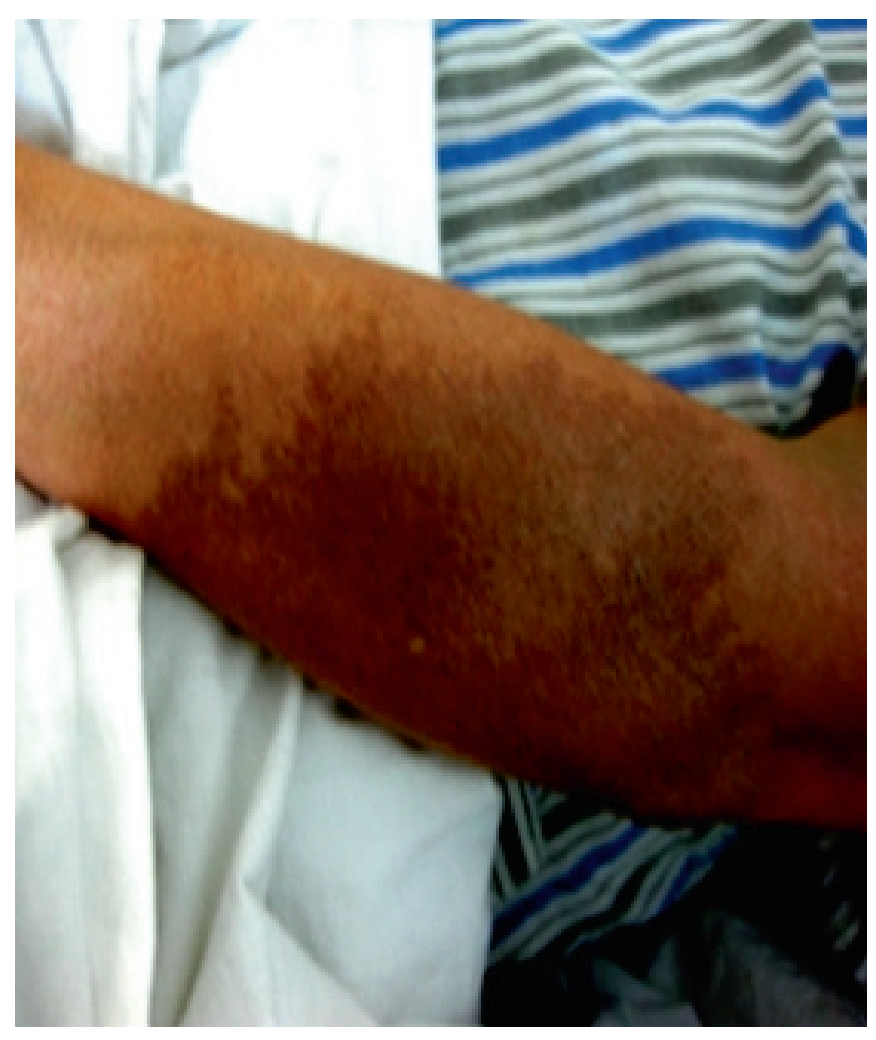

Fig. 1. The breast cancer patient with acquired ichthyosis had scaly erythematous patches on her extremities.

Table 1. The clinical data of 4 breast cancer patients with dermatosis

\begin{tabular}{lllllllllll}
\hline Case & Sex & $\begin{array}{l}\text { Age }^{\text {a }} \\
\text { years }\end{array}$ & Dermatosis & $\begin{array}{l}\text { Lag period } \\
\text { to breast } \\
\text { cancer, } \mathrm{m}\end{array}$ & $\begin{array}{l}\text { Operation } \\
\text { type }\end{array}$ & Pathology & $\begin{array}{l}\text { Metastatic } \\
\text { LN, } \mathrm{n}\end{array}$ & $\begin{array}{l}\text { AJCC } \\
\text { stage }\end{array}$ & Outcome Cause of death \\
\hline 1 & F & 51 & DM & 36 & SM + ALND & primary lymphoma & $13 / 22$ & IIIC & D & respiratory failure \\
2 & F & 53 & DM & 24 & MRM & breast carcinoma in situ & $0 / 17$ & IIA & S & - \\
3 & F & 52 & AI & 36 & MRM & invasive ductal carcinoma & $10 / 25$ & IIIC & S & - \\
4 & F & 67 & DM & 60 & MRM & invasive ductal carcinoma & $14 / 21$ & IIIC & S & - \\
\hline
\end{tabular}

${ }^{\mathrm{a}} \mathrm{Age}$ at diagnosis of malignant breast tumor.

$\mathrm{m}=$ Months; $\mathrm{LN}=$ lymph node; $\mathrm{AJCC}=$ American Joint Committee on Cancer; $\mathrm{F}=$ female $; \mathrm{DM}=$ dermatomyositis; $\mathrm{AI}=$ acquired ichthyosis; $\mathrm{SM}=$ simple mastectomy; $\mathrm{ALND}=$ axillary lymph node dissection; $\mathrm{MRM}=$ modified radical mastectomy; $\mathrm{D}=$ died; $\mathrm{S}=$ survived. 
paraneoplastic event in some patients. A large retrospective study showed that 3-60\% dermatomyositis patients had underlying malignancies [9, 10]. Richardson et al. [11] and Callen $[12,13]$ found that the tumor types seem to roughly parallel those of the general population, with carcinomas of the breast and lung being the most common. In our study, all patients had malignant breast tumors, associated in 3 patients with dermatomyositis and in 1 patient with acquired ichthyosis. The relationship between the onset of dermatomyositis and the diagnosis of malignant breast tumor is uncertain, as seen in the present study and in the literature $[12,13]$. Dermatomyositis may precede the occurrence of the malignancy by months or years, be discovered concurrently with the malignancy, or become evident several months after the malignancy is diagnosed $[14,15]$. In our patients, the 3 cases of dermatomyositis preceded the occurrence of the malignant breast tumors by 24,36 , and 36 months, respectively.

Ichthyoses are a heterogeneous group of cutaneous keratinization disorders with both inherited and acquired forms, characterized by an accumulation of cutaneous scales resembling fish scales. The symptoms consist of severe dryness of the skin with thickening, flaking, and mild itching. Acquired ichthyosis is most commonly seen in the elderly. Its onset is related to the development of an underlying systemic disease [16]. However, the relationship between the onset of acquired ichthyosis and the diagnosis of breast carcinoma is uncertain [3-6]. Acquired ichthyosis may precede the diagnosis of the underlying malignancy by as little as 2 weeks or as much as 10 years [17]. Our case of acquired ichthyosis preceded the occurrence of the malignant breast tumor by 60 months.

We believe that dermatosis associated with cancer may be related to the use of immunosuppressive agents, such as cytotoxic drugs, which lead to a decline in immune surveillance function. For example, the heavy use of hormones can suppress general immune function and also inhibit anti-tumor immune function of the body and accelerate tumor progression. Richardson et al. [11] reported variable influence of the treatment of the associated malignancy on the clinical course of the dermatomyositis. In our study, all patients underwent surgical treatment for the malignant breast tumor; no complications were observed in the postoperative period. Two patients showed parallel improvement of the dermatomyositis, and had recovered from the skin rash and muscle weakness 6 months after the operation. The patient with acquired ichthyosis also showed parallel improvement, and had recovered from the cutaneous scales 2 months after the operation. However, 1 patient with dermatomyositis and primary lymphoma died of respiratory failure caused by interstitial lung disease 2 months after the operation.

In our study, all 4 patients were $>50$ years of age (mean age 55.7 years). None of them had early-stage breast cancer, which may explain the poor results in our study. Our recommendation is that women over 50 years of age presenting with dermatomyositis or acquired ichthyosis should have a thorough physical examination including a breast exam once every 6 months. Breast ultrasonography and mammography make it possible to detect malignant breast tumors early in patients with dermatomyositis or acquired ichthyosis. In addition, most scholars believe that ovarian cancer is often a cause of dermatomyositis [18]. As reported in the literature [19], the serum CA125 test can lead to early detection of ovarian cancer in MD patients (early screening sensitivity $50 \%$, specificity $100 \%$ ). In conclusion, breast cancer screening is necessary in woman with dermatomyositis or acquired ichthyosis, especially in those aged $>50$ years.

\section{Conflict of Interest}

The authors did not provide a conflict of interest statement.

\section{References}

1 András C, Ponyi A, Constantin T, et al.: Dermatomyositis and polymyositis associated with malignancy: a 21-year retrospective study. J Rheumatol 2008;35:438-44.

2 Vaccaro M, Borgia F, Barbuzza O, et al.: Dermatomyositis and cutaneous metastases from breast cancer: simultaneous development and parallel course. Rheumatol Int 2009; Epub ahead of print.

$\checkmark 3$ Haste AR: Acquired ichthyosis from breast cancer. Br Med J 1967;4:96-8.

4 Dugois P, Amblard P, Phelip X, et al.: Acquired ichthyosis as a symptom of breast neoplasm. Bull Soc Fr Dermatol Syphiligr 1972;79:196-7.

5 Polisky RB, Bronson DM: Acquired ichthyosis in a patient with adenocarcinoma of the breast. Cutis 1986;38:359-60.

6 Reiches AJ: Acquired ichthyosis; report of case associated with breast carcinoma. Urol Cutaneous Rev 1950;54:160.
7 Patel N, Spencer LA, English JC 3rd, et al.: Acquired ichthyosis. J Am Acad Dermatol 2006;55: 647-56.

8 Bohan A, Peter JB: Polymyositis and dermatomyositis (first of two parts). N Engl J Med 1975;292: 344-7.

$\checkmark 9$ Sigurgeirsson B, Lindelöf B, Edhag O, et al.: Risk of cancer in patients with dermatomyositis or polymyositis: a population-based study. N Engl J Med 1992;326:363-7.

10 Maoz CR, Langevitz P, Livneh A, et al.: High incidence of malignancies in patients with dermatomyositis and polymyositis: an 11-year analysis. Semin Arthritis Rheum 1998;27:319-24.

11 Richardson JB, Callen JP: Dermatomyositis and malignancy. Med Clin North Am 1989;73:1211-20.

12 Callen JP: Dermatomyositis. Neurol Clin 1987;5: 379-403.

13 Callen JP: Malignancy in polymyositis/dermatomyositis. Clin Dermatol 1988;6:55-63.
14 Yeh CN, Chen SC, Hwang TL, et al.: Breast carcinoma in patients with dermatomyositis: a retrospective analysis of eight cases. Chang Gung Med J 2002;25:374-80.

15 Schiller M, Böhm M, Hensen P, et al.: Dermatomyositis associated with malignant melanoma - a marker of poor prognosis? J Am Acad Dermatol 2006;54:221-6.

16 Norman RA, Blanco PM: Papulosquamous diseases in the elderly. Dermatol Ther 2003;16:231-42.

17 Levy O, Tishler M: Acquired ichthyosis as the primary manifestation of renal cell carcinoma. Isr Med Assoc J 2009;11:121-2.

18 Callen JP: Dermatomyositis. Lancet 2000;355:53-7.

19 Whitmore SE, Anhalt GJ, Provost TT, et al.: Serum CA-125 screening for ovarian cancer in patients with dermatomyositis. Gynecol Oncol 1997;65: 241-4. 